\title{
THE RELATIONSHIP OF CINEMA TO PHILOSOPHICAL THOUGHT: BADIOU AND DELEUZE
}

\author{
Ebru Thwaites Diken
}

\begin{abstract}
Today we live in a cinematic society governed by images and by media culture. Governmentality depends on the staging of social reality through visual dispositifs. Cinema is a significant dispositif in this context. This article first explores the relationship of cinema to modernity and spectacle and to the foundations of modern power. Besides being a governmental dispositif, cinema is also a social phenomenon. Turning social life into representation, cinema not only depicts, but also constructs social reality and shapes the social unconscious. As Bazin (20 I I) has argued, cinema provides its audience with tools with which to philosophize. The article compares Badiou's and Deleuze's approaches to cinema, which suggest that, although the cinematic thought is not reducible to the philosophical, cinema always stages a philosophical encounter, affecting new ways of thinking and being.
\end{abstract}

Keywords: Cinema, philosophy, Badiou, Deleuze, spectacle.

\section{Sinemanın Felsefi Düşünce ile İlişkisi: Badiou ve Deleuze}

Öz

İçinde yaşadığımı toplum imgelerin gerçekliği kurduğu, yönetimselliğin görsel dispositifler (tertibatlar) dolayımıyla sahnelendiği sinematik bir toplumdur. Günümüzde sinema önemli bir yönetişim aygıtıdır. Bu makale ilk olarak modern toplumlarda iktidarın bakış üzerinden nasıl örgütlendiğine, bu temelde de sinemanın modernite ve gösteri kavramıyla olan ilişkilerine odaklanır. Sinema bir yönetişım aygıtı olmasının yanı sıra, aynı zamanda toplumsal bir olgudur. Gerçekliği imgeler yoluyla temsil etmekle kalmaz, aynı zamanda toplumsal gerçekliği ve toplumsal bilinçaltını kurar. Bazin'in (20II) de söylediği gibi, seyircisine felsefi düşünme için gerekli araçları sağlar. Bu makalenin amacı Badiou ve Deleuze'un sinema ve felsefi düşünce hakkındaki görüşlerini karşılaştırmalı olarak incelemektir. Her iki düşünür de sinematik düşüncenin felsefi düşünceye indirgenemeyeceğini, ancak sinemanın her zaman yeni varoluş ve düşünme biçimlerini çağıran felsefi bir karşılaşma olduğunu söylerler.

Anahtar Sözcükler: Sinema, felsefe, Badiou, Deleuze, modernite, gösteri. Sembolik düzen.

Bu çalışma 30 Ekim 2016 tarihinde sinecine dergisine ulaşmış, I I Şubat 2017 tarihinde kabul almıştır. ecthwaites@gmail.com 


\section{Introduction}

\section{Cinema and Philosophical Thinking}

Power and belief always rely on visual mechanisms. Religious rituals and political ceremonies, for instance, are organized for public gaze. The role of the spectacle is to create public approval and ensure the consent of the masses. Historical and contemporary examples like the bread and circuses of the Roman state and reality shows can be multiplied.

Modernity and the spectacle are closely linked. There are different perspectives about how we can historically locate the concept of the "spectacle". The term has been used in differential contexts. In this article we focus on Debord's (1983) conceptualisation which views it as the expression of a totalising effect of power in contemporary capitalism. Debord has also said that the spectacle served as the illusory "opium" of the masses which has taken the place of religion in modernity. Indeed, the spectacle seems to be the most important instrument of governmentality in modern states. It provides entertainment, distracts people's attention, and ensures their passivity.

Cinema seems to hold a privileged position with regard to the spectacle. Cinema is the most obvious art form to observe the spectacle as a historical socio-economic condition. The cinematic medium itself is spectral too (Levin, 2004). Further, being an art and an industry at the same time, cinema is the most compatible medium with the economy of the spectacle.

Some sociological studies have viewed cinema as an ideological state apparatus which reflects cultural properties of different historical epochs. Indeed sociological studies on cinema often find valuable material in films (Casetti, 1999, pp. 108-110). Such studies often deal with films as representations though. According to such perspectives, films either represent the existing socio-political condition or they are sheer fictions that suspend the ordinary course of life and make the spectator escape into a phantasy world.

However, some other approaches ${ }^{1}$ to cinema argue that cinema does more than representing. Most importantly, it thinks. The screen does not necessarily estrange us from life; rather, teaches us to be more prepared for life (Bazin, 2011, pp. 10-11). As such, cinema is indispensable for sociological imagination. In fact cinema can be seen as a site on which sociological imagination is cultivated (Prendergast, 1986).

i.e. Bazin, 2011; Deleuze, 1997, 2000; Badiou, 2013.

128 sinecine $2017>8(\mathrm{I})$ Bahar $>$ Spring 
Badiou and Deleuze both view cinema and philosophy as acts of thinking, albeit in different ways. Neither of them is content with doing the sociology of cinema or film critique as such. Sociology works with concepts. However cinema works with images and affects. For example, Deleuze (2000) analyses films in terms of their image components. He says that cinema thinks through images composed of movement and time. By the same token, films cannot be reduced to their narratives. The relationship between image and thought constitutes the core of Deleuze's cine-philosophy. Central in this respect is the ability of cinema to link the actual and the virtual, opening up the actual social life to a virtual domain of possibilities.

Badiou (2013) is rather concerned with the democratic-egalitarian potential of cinema. For Badiou the most important aspect of cinema is its impurity, because the film enterprise is governed by capitalistic and artistic concerns at the same time. He suggests that films rest on the border between art and non-art. Second, cinematic production often involves other forms of art such as music, theatre, literature, painting and photography. For these two reasons artistic activity in cinema can only emerge through a process of purification through which cinema distances itself to its non-artistic starting point.

It is worth mentioning a fundamental difference between Deleuze and Badiou in terms of their approach to the role of the image in the formation of the cinematic idea. Unlike Deleuze, Badiou does not view the image as central to the formation of the cinematic idea. For Badiou the idea emerges "in the form of a visitation which installs itself in the impure movement between different arts" (as cited in Hair, 2007, p. 66).

Before elaborating on this comparison, in what follows, I explore the foundations of modern power on gaze and argue that modern politics is about establishing a new way of seeing. Then I discuss the relationship between modernity and the spectacle and the role of cinema as a governmental dispositif in this context. On this basis, the article finishes by discussing cinema in terms of its potential to create a democratic, egalitarian society by virtue of being a philosophical, artistic enterprise.

\section{The Social Meaning of the Act of Seeing}

The mediation of vision is integral to the making of modern power; because the sensorial experience of modernity is primarily founded on the gaze (Crary, 1992). For this reason, studies on the sociology of cinema must first consider the social meaning of the act of seeing and visibility. Historically the problem of vision and spectatorship has always concerned the body and 
power (1992, p. 15). It is thus impossible to analyze the gaze as something dissociated from the gazing subject who is both the product and the site of these techniques, institutions and procedures of subjectivation (1992, p. 17).

Power is a relationship of visibility. It involves seeing and being seen. The front cover of Thomas Hobbes' famous book, The Leviathan (1651), works as a classical example to explain how power is constituted by gaze. The picture shows a gigantic human figure who overlooks a town. We only see the upper part of the Leviathan's body which is made up of smaller human figures looking upward at its face. This figure, holding a sword and a wand in its hands, represents the sovereign power - the state in modernity. The people who make up its body refer to the citizens in the modern state. This figure acts as a metaphor for the functioning of modern power. The picture illustrates that the sovereign's power comes from the governed. The people's gaze is what constitutes the source of Leviathan's authority.

This idea is the foundation of Hobbes' theory of social contract and modern government. Hobbes suggested that people can live in peace only if they give up their freedom and transfer their rights to a supreme authority in return for their security. The social contract indicates that the sovereign's legitimacy depends on the fact that people see the sovereign as the sovereign. If the people stop seeing the sovereign as the sovereign, we cannot speak of the legitimacy to rule. Yet, at the same time, whichever angle one looks at the picture from, one feels the inspecting gaze of the Leviathan. Wherever we stand, the object of our gaze stares back at us. This constantly reminds us of our subjection to its authority. In this sense, too, power is founded on visibility. "What we see in the eye of the sovereign is the locus of one's own seeing in the alien form of blind spectacle - as artifice" (Pye, 2015, p. 172).

Foucault suggests that, in modernity, the relationship of visibility and power takes the form of the Panopticon. He uses Bentham's prison as a model for the operation of modern power (1991, pp. 200-202). It is a round building with a watchtower at its centre. Each floor of the building is made up of cells with windows through which light comes in. Although the occupants of the cells can be seen by the watch tower, they cannot know whether they are being watched or not. Moreover, the walls between the cells also prevent the inmates to contact other inmates, so they are isolated and individualized in their actions.

The effect of the Panopticon induces in the inmates a state of permanent visibility which leads them to exercise auto-control all the time. Foucault (1991) suggests that this panoptic organization in Bentham's prison is replicated in other modern institutions too (i.e. the schools, hospitals, mental 
asylums, the army and the factory). It enables the exercise of power based on the practice of seeing without being seen. In these institutions, all aspects of life come under the gaze of the sovereign power and power is exercised through disciplining bodies under surveillance. It is important to highlight that by developing the notion of the norm, the panoptic institution serves to discipline not only the delinquents inside, but also the citizens outside for whom the panoptic is reminder of what follows the transgressive behaviour. As such, the prison is closely integrated with its outside, the society.

The disciplinary and biopolitical techniques reached their peak after the Second World War (Fuglsang \& Sorensen, 2006, p. 179). One can reasonably state that the 1968 student movement was in a sense a rebellion against the panoptic power structures controlling the society. After the 1970s, however, with the emerging new post-Fordist capitalism, the disciplinary techniques of confinement were no longer adequate for economic and political reproduction. Thereby, the institutions of the discipline society entered into a state of crisis (Deleuze, 1999).

The basic thesis Deleuze articulates in his short but influential article, titled "Societies of Control", concerns the gradual replacement of "discipline" with "control" as the dominant dispositif of the modern society (1999, p. 174). While the panoptic model worked through the geographically fixed sites of containment, control involves more mobile, flexible and unbound techniques.

It is important to note that this shift does not mean the disappearance of discipline as such. Discipline still exists in control societies but it is no longer practiced in panoptic sites of enclosure. Control extends discipline to the whole social space. In this sense "control knows no outside" (Hardt \& Negri, 2000, p. 413). In disciplinary societies, people moved from one enclosed space to another (i.e. from the family to the school, from the school to the military service, from the military to the workplace, etc.). In each institution, the subject started a new process of subjectivation. In control societies, however, people never finish anything (Deleuze, 1999, p. 179). "Education takes the form of life-long learning; relations in the workplace become family-like; and so on" (Deleuze, 1999, p.179).

In control societies, the gaze of the sovereign power does not come from one focal point as in the Panopticon. Instead, the gaze is fragmented. The power mechanism still rests on seeing without being seen, but it is no longer the watchtower which inspects the subjects. Rather, people are surveilled by many watchtowers - namely the CCTV camera, facebook, and other digital media. Their mobile gazes record people's every single movement and make it available for management. 
Let us look at power as a relationship of visibility from the perspective of the subject. From the subject's viewpoint, being seen is an ontological desire. In daily interactions people are often concerned about their image in the eyes of others. To address this, Goffman (1956) developed the concept of dramaturgy, suggesting that social life is a stage. Socialization involves learning to act roles. All social actors mirror one another in this, trying to manage their images in the eyes of others. The subject constitutes itself in relation to the others' gaze.

Along the same lines, the psychoanalytic theory argues that the subject constitutes herself vis-a-vis the Big Other, which is a stand-in for the sociosymbolic space, for society. This symbolic space does not only include rituals, institutions, state and God but also refers to language through which the subject establishes a relationship to culture from when s/he is born (Salecl, 1998, p.21). In this perspective our image of a coherent and a complete self is a phantasy which can only be sustained through others, vis-à-vis the Big Other that can mirror this image. In this context, gaze corresponds to "the desire for self-completion through another" (cited from Olin, by Schroeder, 2002, p. 58).

Herein lies the reason why gaze is constitutive of power. Gazing, in other words, means more than just looking. "It signifies a psychological relationship of power" (Schroeder, 2002, p. 58). And in so far as the relationship between the one who gazes and the subject of gaze has a political nature, politics always involves a desire to establish an alternative way of seeing and being seen. As such, politics is an aesthetic configuration, an attempt to configure a new stage on which subjectivity and the sensory and the cognitive experience of visuality can be reframed.

\section{The Meaning of the Spectacle in Modernity and Post- modernity}

With modernity, the spectacle has obtained a metaphysical character. It appears today in many different social contexts, determining social relations and the perception of the self (Debord, 1983). Debord defines the spectacle as the "material reconstruction of the religious illusion". Just as religion consists in transference, in humans' transfer of their own good attributes such as love, friendship, and justice to an external Other and objectify an ideal conception of themselves as "God" (Feuerbach, 2012), in modernity humans are objectified (and thus alienated) through the spectacular technology (1983, p.20). Thus Debord sees the spectacle as the "opium" of modern society. The subject relates to the society of spectacle as a "pseudo-sacred entity" (Debord, 1983, p. 9). Hence the spectacle becomes the "locus of illusion and false 
consciousness" (1983, p. 2).

But the society of the spectacle is more than an image saturated society. It defines the way in which people relate to others. The spectacle "is a social relation among people, mediated by images". In the process of establishing this social relation, people's gaze at each other is deceived (Debord, 1983, p. 2). In this sense, false consciousness characterizes the spectacle. People all gaze at the same thing. Thus the spectacle seems to unify people.

At the same time, however, the spectacle separates subjects, creating isolate and disempowered individuals (Debord, 1983, p. 29). Just like the inmates do not see each other in the Panoptic machine, individuals in the spectacle are individualized and cannot relate to one another. In this sense the term refers to a socio-economic condition where social cohesion takes place only through the global market, where people can come together only as consumers.

Worse still, the spectacle pre-fabricates their desires and pre-emptively shapes their psyche. This is necessary to sustain the totality of this commodityworld. Commodification dominates all aspects of life in the society of the spectacle. Consequently, the tangible world tends to be replaced by images which impose themselves as tangible (Debord, 1983, p. 36). The commodity becomes "all one sees" (1983, p. 42). That is, the social world Debord is describing is not split into reality and image. On the contrary, "the spectacle itself is real" (1983, p. 3).

But is the spectacle merely a capitalist super structure as Debord suggests? Comparing Debord and Baudrillard can be useful to elaborate on this question. Baudrillard operates with an ideal-temporal differentiation between pre-capitalist societies organized around symbolic exchange, modern societies organized around production and labour, and post-modern societies organized around simulation (1993, p. 8). The contemporary (post-modern) society, in this perspective, is characterized by the implosion of a (modern) social structure organised around the concepts of work and production. With post-modernity, economic reproduction based on work is to a high extent replaced by social reproduction based on communication and knowledge. Social relations are no longer determined by the production and consumption of use and exchange value but they increasingly depend on the production of signs and images, of "sign value" (Baudrillard, 1998, p. 190). Consequently, meaning disappears into arbitrarily floating images (Seppanen, 2006, p. 40).

Similar to Debord, Baudrillard sees alienation as total. However, the key constituent of society for Baudrillard is the hyper-reality of simulation. 
Hyper-reality signifies the end of the social. For the masses seek the spectacle, not meaning (Baudrillard, 1983). Debord's analysis presumes the existence of an originary reality (which is then progressively eroded by the spectacle). But in Baudrillard the very illusion of reality disappears. He pushes Debord's critique of the spectacle to a hyperbolic extreme. Thus in hyper-reality, even the critique of the spectacle itself becomes a spectacle.

We no longer partake the drama of alienation, but are in the ecstasy of communication. And this ecstasy is obscene. Obscene is that which eliminates the gaze, the image and every representation. Obscenity is not confined to sexuality, because today there is a pornography of information and communication (Baudrillard, 1988, p. 22).

A society in which the reality principle disappears is a "cinematic society" - a Disneyland, an archetypal simulacrum in which the real and the fictive coincide (Baudrillard, 1988, p. 56). Already Benjamin had suggested that although the environment we live in seems so suggestively real, given and natural, it is a socio-economic construct. In this phantasmatic space or "phantasmagoria", "the most obvious things like the historical present or the physical aspect of the environment are denied to us" (2008, p. 11). With Baudrillard (1993), however, "phantasmagoria" designates the extinction of the real in the simulacra. In the spectacle, things become real through the claim that they are imaginary. Baudrillard suggests in this context that the real function of Disneyland is to hide the fact that the rest of the world is fake (1993, p. 12). ${ }^{2}$ As such Baudrillard says that cinema, along the same lines, hides the fact that the rest of the society is cinematic. Thanks to cinema, we are able to maintain the sustainability of our illusion of reality $(2005$, p. 94$)$.

\section{Cinema as Reality}

To better understand how cinema operates as part of a spectacle, it is fruitful to say a few words on the transition from theatrical to cinematic representation. This transition is significant in terms of the distance created between the art work and its receptor ${ }^{3}$. Up to the 1940 s, there was a widespread view that theatre and cinema "were separate but equal" (Mackinnon, 2013, p. 5). Each had its own artistic potentialities and each had developed separately

2 Foucault had shown that the whole modern socity was Panoptic in its organization; the Panoptic prison merely hides this fact.

3 Although there are significant differences between theatrical and cinematic representation, there has been a lot of exchange between cinema and theatre in the nineteenth century too. For instance, Charlie Chaplin is known to have imported music hall techniques to cinema (MacKinnon, 2013, p. 6). It is also well known that the directors, actors and actresses generally moved from theatre to cinema. 
within their own stylistic and thematic domains (2013, p. 5). However, cinema surpassed theatre in its ability to play with time, space and movement (2013, p. 4). Today there is an unbridgeable gap between the two, especially in terms of their mediation capacity. "Cinema operates not only by showing but also by dictating how what is shown is to be seen" (2013, p. 15).

Against this background, "films are never 'just films', light-weight fiction destined to amuse us and thus to distract us from the core problems and struggles of our social reality. Even though filmic images do not constitute actual reality, they are nevertheless real in terms of their potential to open the actual world to the domain of virtual possibilities (Diken \& Laustsen, 2008, p. 3-5). In this respect films testify to the dialectic relationship between reality and fiction (between the actual and the virtual).

Films are sites on which reality is constructed. After all, social reality itself rests on ideological illusions. Illusion is always necessary to sustain the reality of the political. Thus it is difficult to sustain a clean-cut division between reality and fiction, between society and cinema. Indeed, in the society of the spectacle the events tend to take place in cinema before in real life. The movie which best captures the focal point of this approach in its narrative is The Purple Rose of Cairo (Woody Allen, 1985). The film plays with the uncanny relationship between reality and phantasy. The main character, Cecilia, a waitress, is unhappy with her husband who is a violent alcoholic gambler. So she escapes her daily reality by going to cinema. She always watches the same movie, The Purple Rose of Cairo. Gradually she becomes obsessed with the main character - the archeologist Tom Baxter. She tells her sister: "I found a wonderful man. He is fictional, but you can't have everything".

Her phantasy life becomes more important to her than the real world around her. However one day the fictional character turns out to be real. Tom Baxter notices her. He steps down and walks off the screen. They hold hands and leave the place together. The other characters remain in the same shot, playing cards. The audience, too, starts to wait to see what will happen. In the meantime the film's producer and other Hollywood executives start wandering in town to find Cecilia so that she convinces Tom to return to the screen. Otherwise, the film would make a loss. If the same thing happens elsewhere and all fiction becomes reality, the movie sector would face a crisis. Then people will have no place to escape their daily life.

In the film the power relationship between the spectator and cinema is reversed. Critical approaches to Hollywood cinema suggest that it makes a profit by preparing the people for another working day. We see in The Purple Rose of Cairo that if the spectator opts out it becomes all too visible that 
the power of cinema is constituted by the spectators' gaze. In this sense The Purple Rose of Cairo can also be taken as metaphor for the hyper-real society in which fiction defines the real.

\section{A Thinking Cinema...}

\section{Deleuze's Cine-Philosophy}

As mentioned above, philosophy thinks with concepts and cinema thinks with images. Social phenomena can be analyzed in terms of causal relationships. However, images cannot be thought of in the same way, because images do not render exact interpretations. Social theory needs to classify images to make sense of films. In this context the relationship between images and concepts constitutes the core of Deleuze's film philosophy. The classification Deleuze provides refer to different modes of film making: the time image and the movement image.

Deleuze's film philosophy is not a theory on cinema. Films cannot be reduced to their narratives. For Deleuze, cinema is just a form that thought assumes. It creates concepts in a philosophical way. Thus new assemblages between cinema and philosophy occur. "Philosophy produces concepts which are in resonance with today's cinematographic images" (Deleuze, 1997, p. xi). ${ }^{4}$

However, cinema creates concepts through time and movement images. Images which display movement are movement images; whereas images which intertwine movement with duration are time images. Any image which displays a certain aspect of the world for the spectator is filtered through the spectators' perception. Thus, time and movement images are also perception images, because they are presented to our consciousness (Deleuze, 1997, p. 64). Overall, if the universe as the place of immanence is a cinema, then it can be seen as a set of movement images and blocs of space-time. Significantly, movement images take on three varieties such as perception images, affection images and action images (1997, p. 68). A film is as such an assemblage of these three kinds of images, yet, generally speaking, one of the three kinds of images tends to become dominant in any film.

In films based on the movement image, images follow each other within a relationship of causality just like thoughts do. Everything finds their place in

4 This is from the translators' note (of Deleuze's book, Cinema I: the Movement Image). The quote is taken from an interview that Herve Guibert had made with Deleuze. The interview has been published in Le Monde on the 6th of October, 1983. 
temporal terms (Rushton \& Bettinson, 2010, p. 114). Thus the narrative events that constitute the film can be listed on a timeline on which the past, present and future can clearly be discerned from each other. It follows that images are designed to achieve a result; the film characters work towards a goal; and the shots are linked with each other in terms of cause and effect relations (2010, p. 120).

In contrast, with the time image, "not everything has its place" (Rushton \& Bettinson, 2010, p. 120). An example of a film of time images is Citizen Kane (Orson Welles, 1941). This film presents the spectator with subjective accounts of Kane which contradict each other (2010, p. 120). After watching the movie, the audience cannot place the past, present and the future on a timeline. The images on the film screen gain a temporal perspective. The characters do not act upon certain events, but "what they see or hear serve as catalysts to their memory" (2010, p. 121).

For Deleuze, the crucial turning point in the history of cinema is the Second World War because the shift from movement image to time image occurred during this period (1997, p. 206). For the war meant the emergence of a nihilistic moment in which it became difficult for art to make sense: the link between action and situation, between action and reaction was broken (1997, p. 207). A new type of space without differentions, what Deleuze calls 'any-space-whatever', corresponded to this nihilistic moment. As such the main characteristic of the post-war cinema is the dominant use of the timeimage, that is, the lack of a cause and effect chain between images, a rational track between events, and a hierarchic order between ideas in the narrative. The time images constitute singularities that are combined only in "anyspace-whatever" (Rodowick, 1997, p. 65). In a sense, therefore, "any-spacewhatever" refers to the undoing of space, story, plot and action (Deleuze, 1997, p. 208).

The idea of "any-space-whatever" is constitutive for Deleuze's sociology, especially for his conception of 'control society', the 'smooth' surface of which consists of "any-space-whatevers" - spaces that people pass through, spaces that have no certainty, such as metros, airport terminals, and etcetera. To conclude the affinity between the sociological concept of control and the cinematic concept of time-image (based on any-space-whatevers) demonstrates that the screen is an aesthetic and a political territory.

\section{Badiou's Cinema as Idea}

Badiou views films as political and aesthetic weapons. His main concern is to put cinema into use towards an emancipatory politics $(2013$, p. 8). Thus 
he is interested not only in the artistic propositions of a film, but also in "what the film takes a stand on and which cinematic form it takes" (2013, p. 11). Films tell something about their era. Hence what is significant about a film according to Badiou is what remains in the spectators' minds once they leave the movie theatre.

Cinema is a "metaphor for contemporary thought" Badiou suggests - almost reminiscent of the way in which the tragedies had functioned as a metaphor for thought in the ancient Greece (Badiou, 2013, p. 17). In a similar way, today's cinema can be compared to what the novel was to the $19^{\text {th }}$ century: cinema is a "democratic amblem" of the twentieth century by virtue of being a "mass art" (2013, p. 233). Cinema embodies a paradox due to being a mass art: the mass is a political category of democracy, whereas art is an aristocratic category - for creation requires apprenticeship and education (2013, pp. 234235). This paradoxical relationship is what concerns philosophy about cinema. The concept of the image is central in Badiou's approach to this paradox. Cinema works with images and therefore is the "high point of the visual as semblance" (2013, p. 236). Since the spectators' identification is based on semblance and "semblance renders the religious fable obsolete" (2013, p. 236). Therefore films become the fables of the modern era. Significantly in this respect, cinema is always in a relationship to other forms of arts. As a mass art, cinema popularizes the other arts and strips them off their aristocratic components. Indeed, cinema becomes democratic through the popularization of the other arts (2013, p. 238).

Badiou differs from Deleuze in his attempt to reconfigure the place of truth in cinema (2000, p. 20). Cinema as a producer of truth has a major role in shaping subjectivity. While at the same time Deleuze shares with Badiou a common conception of truth linked with an event. However, it is important to note that they have a different perspective on the concept of truth. For Deleuze, truth is an immanent value in itself. For Badiou however truth is an event which one can give meaning to, through one of the four truth-procedures: art, love, politics and science. What produces the truth-event in cinema is not the narrative, the plot or the images; but, it is one individual element in the film which "touches upon a form of the universal" (Badiou, 2003, p. 18). Cinema's strength lies in turning the impurity of its heterogeneous starting point (cinema being an art and an industry at the same time) into an idea in its own right (2013, p. 93).

There are of course affinities between art and politics. Both of them are processes of creation. As such, they are not connected with a relationship of hierarchy (i.e. as in art work representing a political idea or a political idea 
induced from the representational force of art work) (Badiou, 2013, p. 114). However, films do not need to have explicit political purposes. Nevertheless, films which are not explicitly political (i.e. romantic comedies for instance) can have real political impacts. For this reason one should rather focus on how films treat an idea (2013, p. 88). Cinema's true potential to be emancipatory lies in its impurity, in its potential to distill an idea from impurity. By the same token, the idea is really what draws any critical sociology to cinema.

\section{Concluding Remarks}

Overall, this article illustrated the relationship of cinema to philosophical thinking and described the ways in which Badiou and Deleuze described affinities between philosophical thought and cinema. As mentioned above, Deleuze describes cinema as a form which thought assumes; and Badiou describes it as an aesthetic and a political site from which an idea is distilled. Indeed for both accounts cinema is a significant political and an aesthetic territory. Cinema thinks, produces ideas which cannot be reduced to concepts and narratives and works with images. Through popularizing and mythologizing, it serves as the most obvious art form to create a spectacle. It also makes the other art forms accessible to public and thus contributes to a democratic culture. By doing so, it speaks to our collective way of thinking about the world. This article concludes by saying that cinema creates an impact on politics which is about establishing a new way of seeing and creating a new spectacle.

"Of all spectacles cinema is even the only one I do like" (Pawlett \& Dhanda, 2010, p. 116, citing from Baudrillard).

\section{Bibliography}

Badiou, A. (2000). Deleuze: The clamor of being (L. Burchill, Trans.). Minneapolis: The University of Minnesota.

Badiou, A. (2013). Cinema (S. Spitzer, Trans.). Cambridge: Polity.

Baldwin, J. (2010). White magic: Baudrillard and cinema. FilmPhilosophy, 14(2), 1-5.

Baudrillard, J. (1983). In the shadow of the silent majorities, ... or the end of the social and other essays (Foss, P.; Patton, P. \& Johnston, J., Trans.). New York: Semiotext (e).

Baudrillard, J. (1988). Jean Baudrillard: Selected writings (M. Poster, Ed.). Stanford: Stanford University. 
Baudrillard, J. (1993). Symbolic exchange and death (I. H. Grant, Trans.). London: Sage.

Baudrillard, J. (1998). The consumer society: Myths and structures. Paris: Gallimard

Baudrillard, J. \& Witwer, J. (2000). The vital illusion. New York: Columbia University.

Baudrillard, J. (2005). The intelligence of evil and the lucidity pact (C. Turner, Trans.). Oxford: Berg.

Bazin, A. (2011). Sinema nedir? (İ. Şener, Trans.). Ankara: Doruk

Benjamin, W. (2008). The work of art in the age of technological reproducibility, and other writings on media. (Jennings, M.; Doherty, B. \& Levin, T., Eds.). Harvard: Harvard University

Casetti, F. (1999). Theories of cinema, 1945-1995. University of Texas: Austin.

Coleman, F. (2011). Deleuze and cinema: The film concepts. Oxford: Berg.

Coulter, G. (2010). Jean Baudrillard and cinema: The problems of technology, realism and history. Film-Philosophy, 14(2), 6-20.

Crary, J. (1992). Techniques of the observer: On vision and modernity in the $19^{\text {th }}$ century. Cambridge, London: MIT.

Debord, G. (1983). The society of the spectacle. Detroit: Black and Red.

Deleuze, G. (1997). Cinema I-The movement image (H. Tomlinson \& B. Habberjam, Trans.). London: The Athlone.

Deleuze, G. (1999). Foucault. London: Continuum

Deleuze, G. (2000). Cinema II-The time image (H. Tomlinson \& B. Habberjam, Trans.). London: The Athlone.

Diken, B. \& Laustsen, C. (2008). Sociology through the projector. London: Routledge

Elden, S.; Lebas, E. \& Kofman, E. (Eds.). (2003). Henry Lefebvre-Key writings. New York \& London: Continuum.

Feuerbach, L. (2012). The essence of Christianity (G. Elliot, Trans.). www.digireads.com

Foucault, M. (1991). Discipline and punish: The birth of the prison (A. Sheridan, Trans.). London: Penguin. 
Fuglsang, M. \& Sorensen, B. M. (Eds.). (2006). Deleuze and the social. Edinburgh: Edinburgh University.

Gilles, D. (1999). Negotiations (M. Joughin, Trans.). New York: Columbia University.

Goffman, E. (1956). The presentation of self in everyday life. Edinburgh: Edinburgh University.

Hair, L. (2007). Badiou/Deleuze: Art and cinema. (Unpublished Doctoral Dissertation). State University of New York, Buffalo.

Hardt, M. \& Negri, A. (2000). Empire. Cambridge, London: Harvard University.

Levin, T. (2004). Dismantling the spectacle: The cinema of Guy Debord. In T. McDonough (Ed.), Guy Debord and the situationist international: Texts and documents (pp. 321-444). Cambridge, London: MIT.

Ling, A. (2006). Can cinema be thought? Alain Badiou and the artistic condition. Cosmos and History: The Journal of Natural and Social Philosophy, 2(1-2). http://cosmosandhistory.org/index.php/journal/ article/view/38/76

Mackinnon, K. (2013). Greek tragedy into film. London \& New York: Routledge.

Navaro-Yashin, J. (2002). Faces of the state. Princeton: Princeton University.

Pawlett, W. \& Dhanda, M. (2010). The shared destiny of the radically other: A reading of The Wizard of Oz. Film-Philosophy, 14(2), 113-131.

Prendergast, C. (1986). Cinema Sociology: Cultivating the Sociological Imagination through Popular Film. Teaching Sociology, 14(4), 243-248.

Pye, C. (2015). The Storm at sea: Political aesthetics in the time of Shakespeare. New York: Fordham University.

Rushton, R. \& Bettinson, G. (2010). What is film theory? Berkshire: Open University.

Rodowick, D. N. (1997). Gilles Deleuze's time machine. Durham \& London: Duke University.

Reine, M. (2014). Adaptation as "transcultural mimesis". In D. Miyao (Ed.), The Oxford handbook of Japanese cinema (pp. 101-124). Oxford: Oxford University. 
Salecl, R. (1998). (Per)versions of love and hate. London \& New York: Verso.

Schroeder, J. (2002). Visual consumption. Oxon: Routledge.

Seppanen, J. (2006). The power of gaze: An introduction to visual literacy. New York: Peter Lang. 